\title{
Mineral Cycling and pH Gradient Related with Biological Activity under Transient Anoxic-Oxic Conditions: Effect on P Mobility in Volcanic Lake Sediments
}

\author{
D. C. Ribeiro, ${ }^{*},+\neq$ G. Martins, ${ }^{\ddagger}$ R. Nogueira, ${ }^{\S}$ and A. G. Brito ${ }^{\ddagger}, \|$ \\ ${ }^{\dagger}$ CIIMAR/CIMAR - Interdisciplinary Centre of Marine and Environmental Research, University of Porto, Rua dos Bragas, 289, \\ 4050-123 Porto, Portugal \\ ${ }^{\ddagger}$ Centre of Biological Engineering, University of Minho, Campus de Gualtar 4700-057 Braga, Portugal \\ ${ }^{\S}$ Institute of Sanitary Engineering and Waste Management, University of Hannover, Welfengarten 1, D-30167 Hannover, Germany \\ "Institute of Agronomy, Department of Biosystems Sciences and Engineering, University of Lisbon, Tapada da Ajuda, 1349-017 \\ Lisbon, Portugal
}

Supporting Information

ABSTRACT: Phosphorus (P) mobility from the sediments to the water column is a complex phenomenon that is generally assumed to be mainly redox sensitive and promoted by anoxic conditions. Thus, artificial aeration of the hypolimnium has been used as a remediation technique in eutrophic water bodies but several times with unexpected disappointing results. To optimize lake restoration strategies, the aim of the present study is to assess the $\mathrm{P}$ flux from the sediments under transient anoxicconditions and to identify the relevant drivers. $\mathrm{P}$ sequential extraction, microprofiling (of $\mathrm{pH}, \mathrm{O}_{2}$ and $\mathrm{H}_{2} \mathrm{~S}$ ), and bacterial community identification were performed on a sediment microcosm approach. The results demonstrated that the overall $\mathrm{P}$ release from sediments to the water column during transient phase was higher during the oxic phase, mainly from $\mathrm{pH}$ sensitive matrixes. The microprofiles signature suggests that the observed $\mathrm{pH}$ gradient during the oxic phase can be a result of $\mathrm{H}_{2} \mathrm{~S}$ oxidation in suboxic layers spatially separated and pared to $\mathrm{O}_{2}$ reduction in top layers, through an electroactive bacterial network. These findings point to an additional driver to be considered when assessing $\mathrm{P}$ mobility under transient anoxic-oxic conditions, which would derive from $\mathrm{pH}$ gradients, built on the microbial electrical activity in sediments from freshwaters volcanic lakes.
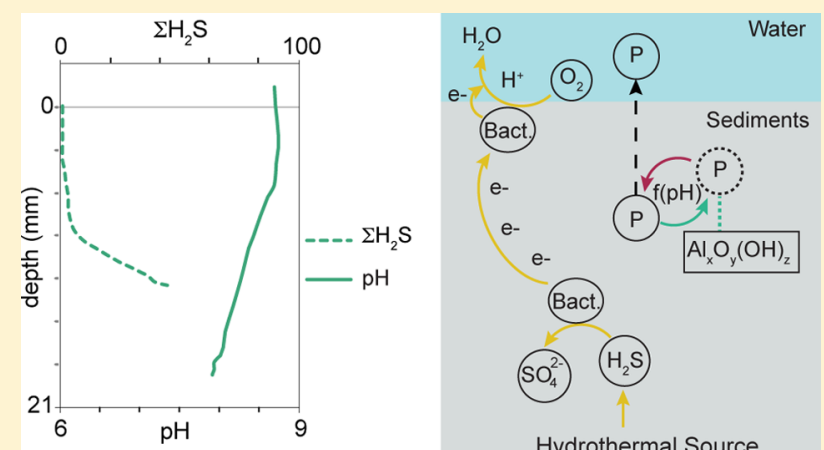

Hydrothermal Source

\section{INTRODUCTION}

Phosphorus $(\mathrm{P})$ is usually the limiting nutrient of eutrophication and algae blooms in lake ecosystems. ${ }^{1}$ Although external $\mathrm{P}$ sources are unquestionable pressures leading to eutrophication, the impact of internal inputs from $\mathrm{P}$ enriched sediments has been identified as very significant, namely when external loads are eliminated. ${ }^{1}$ Several authors state that oxygenated sediments retain $\mathrm{P}$ by fixation to $\mathrm{Fe}$ (III) minerals while, during anoxic conditions, reduced sediments release phosphorus by reduction of iron and subsequent dissolution of ironphosphorus solid phase. These statements are based on the model first proposed by Einsele $^{2}$ and latter supported by Mortimer. $^{3-5}$

According to such concept, intermittent artificial aeration systems designed to maintain oxic conditions when hypolimnetic anoxic conditions prevail were applied in some lakes (e.g.: Lake Furnas - Portugal, Lake Sempach - Switzerland). However, the chemical pathways of phosphate release from the sediments under those circumstances are controversial., ${ }^{6,7}$ Indeed, while oxic condition may favor the stability of $\mathrm{P}$ adsorption on iron minerals, several mechanically oxygenated lakes continue to release phosphorus from sediments to the water column with minor or any change in the eutrophication state of the lakes. ${ }^{8,9}$ Additionally, it is remarkable that in some lakes with anoxic hypolimnium, the $\mathrm{P}$ release rate is not significantly different comparing with the oxic period of the hypolimnium. ${ }^{10,11}$ These observations point to other biogeochemical mechanisms involved in P release from sediments.

Lake sediment geochemistry is different from lake to lake and thus, remediation techniques should be designed accordingly to the dominant diagenetic processes. ${ }^{12}$ It has been demonstrated that $\mathrm{P}$ can be released from vivianite dissolution due to interaction with hydrogen sulfide, a process that is driven in deep sediment layers where oxygen cannot diffuse-and thus having no influence in $\mathrm{P}$ retention. ${ }^{8,13}$ Therefore, in lakes with

Received: February 28, 2014

Revised: July 24, 2014

Accepted: July 24, 2014

Published: July 24, 2014 
high hydrogen sulfide production, such as volcanic lakes, ${ }^{14}$ this process can have a major effect in P release from deep layers, or during anoxic periods.

Besides iron minerals, other nonredox sensitive minerals can release bounded $\mathrm{P}$ due to $\mathrm{pH}$ shifts. ${ }^{15}$ Recently, Nielsen et al. have demonstrated that the development of a $\mathrm{pH}$ gradient in marine sediments can be associated with hydrogen sulfide oxidation in deep layers coupled with oxygen reduction present in the top layer. ${ }^{16}$ Such electrochemical process spatially separated was thought to be conducted by an electroactive bacterial network. ${ }^{16,17}$ Even more recently, filamentous "cable bacteria" were found to be present in the same marine sediments with these electrochemical capabilities. ${ }^{18,19}$ While additional experiments are made to understand if a bacterial network or cable bacteria or both are oxidizing $\mathrm{H}_{2} \mathrm{~S}$ in deep layer with concomitant production of a $\mathrm{pH}$ gradient, a question arise: what is the impact of this process on mineral cycling and P mobility?

Therefore, the aim of the present work is to identify drivers of $\mathrm{P}$ mobility under transient oxic-anoxic condition in volcanic lakes. Sediments phosphorus sequential extraction (PSE) process and profiling techniques with microsensors to monitor $\mathrm{pH}, \mathrm{O}_{2}$ and $\mathrm{\Sigma H}_{2} \mathrm{~S}\left(\left[\mathrm{H}_{2} \mathrm{~S}\right]+\left[\mathrm{HS}^{-}\right]+\left[\mathrm{S}^{2-}\right]\right)$ concentration in the sediment pore water were carried out. In addition, a screening for iron reducing bacteria with bioelectrical properties was performed.

\section{MATERIALS AND METHODS}

Sediment Sampling and Microcosm Experiment Setup. The collected sediments belong to the shallow volcanic lake Furnas, located in the archipelago of Azores (Portugal) in S. Miguel Island. ${ }^{14}$ Sediment samples were collected at $12 \mathrm{~m}$ deep locations of the lake. A gravitational corer (from Uwitec) with tubes of $6 \mathrm{~cm}$ in diameter and $60 \mathrm{~cm}$ in length penetrated approximately $18-40 \mathrm{~cm}$ in the sediments. The first $10 \mathrm{~cm}$ of sediments were collected (using an Uwitec cutting apparatus) and preserved at $4{ }^{\circ} \mathrm{C}$, while the rest of the sediments were rejected.

In the microcosm experiment, the sediments were homogenized and placed in three tubes $\left(0.1247 \mathrm{dm}^{3} /\right.$ tube $)$ inside a parallelepiped reactor filed with the lake's hypolimnetic water (1.412 $\mathrm{dm}^{3} /$ reactor). The water was analyzed for SRP and total $\mathrm{P}$ (after acid digestion, explained next) through molybdenum blue/stannous chloride colorimetric method. ${ }^{22}$

Two equal reactors were connected allowing the water to circulate in a closed loop from a reactor to the contiguous one (Figure 1). The water temperature of the reactors was controlled with a Nüve BS302 refrigerating system. The experiment was divided in five different phases as schematized in Figure 1. In the first phase, the three tubes of each reactor were filled with homogenized sediments, leaving approximately $1 \mathrm{~cm}$ of headspace in each tube. A small amount of homogenized sediment was taken for PSE setting the initial conditions. The temperature was set to approximately $17^{\circ} \mathrm{C}$. Both reactors were sealed in order to prevent oxygen diffusion to the water, after nitrogen bubbling to complete anoxia. After $24 \mathrm{~h}$, all the sediment settled and the second phase started for a period of 21 days in complete anoxia. At the end of the second phase, the reactors were opened for microprofiling of $\mathrm{pH}, \mathrm{O}_{2}$ and $\Sigma \mathrm{H}_{2} \mathrm{~S}$. During measurements, nitrogen was bubbled in order to restrain oxygen diffusion and keep the reactors in anoxic state.

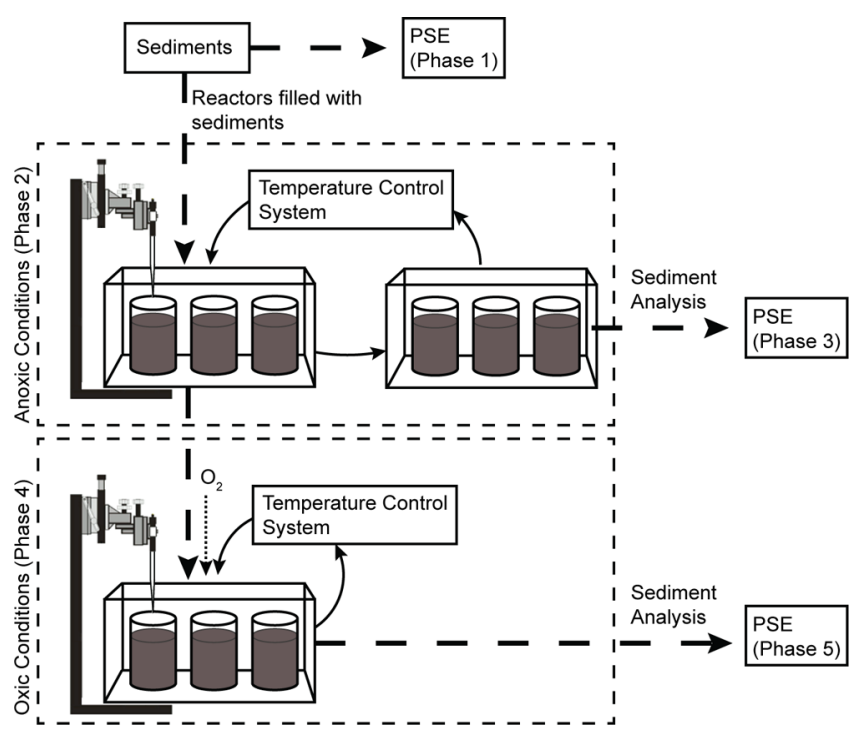

Figure 1. Representation of the different phases (1-5) of the experiment. The $\mathrm{P}$ sequential extraction (PSE) is made before the transference of sediments to the reactors (phase 1), before the change in $\mathrm{O}_{2}$ concentration (phase 3), and at the end of the experiment (phase 5). Measurement of $\mathrm{O}_{2}, \mathrm{pH}$ and $\mathrm{\Sigma}_{2} \mathrm{~S}$ was performed at the end of the anoxic (phase 2) and oxic periods (phase 4) through microprofiling technique. Dashed lines indicate the route of the sediments across the five phases. Dotted line indicates the $\mathrm{O}_{2}$ flux to the reactor in phase four, and solid lines indicate the overlying water flux between the temperature control system and the reactors.

In the third phase, one of the reactors was unplugged from the system for water and sediment analysis. Soluble reactive phosphorus (SRP) in the overlaying water was determined (method described in the Phosphorus Extraction and Analysis section). A sediment sample was taken from the uppermost 2$3 \mathrm{~mm}$ from each tube (approximately $2 \mathrm{~g}$ of wet sediment) for PSE, just after the microprofiling (at the end of the second phase). The reactor that remained in the experimental system was opened to air allowing the diffusion of oxygen into the water.

The fourth phase was executed exactly the same way as the second phase, with the only difference of keeping the reactor open, with air bubbling in the water to produce oxic conditions at the sediment-water interface (SWI). This phase lasted for 21 days, ending with a microprofiling measurement of $\mathrm{pH}, \mathrm{O}_{2}$ and $\Sigma \mathrm{H}_{2} \mathrm{~S}$. The fifth phase was performed in the same way as the third phase. The SRP in the water was determined and approximately $2 \mathrm{~g}$ of wet sediment was collected for PSE.

Microsensor Profiling. Profiles of $\mathrm{pH}, \mathrm{O}_{2}$, and $\Sigma \mathrm{H}_{2} \mathrm{~S}$ concentration in the interstitial water of the sediment were made with microsensors. The profiles were made in the first 20 $\mathrm{mm}$ (maximum depth) of the sediment. The vertical resolution used in this experiment was $250 \mu \mathrm{m}$ (80 measured points in the sediments). The microsensors used were OX-50, $\mathrm{pH}-50$ and $\mathrm{H}_{2} \mathrm{~S}-50$ for oxygen, $\mathrm{pH}$ and $\mathrm{H}_{2} \mathrm{~S}$ respectively (all with a $50 \mu \mathrm{m}$ diameter tip) from Unisense.

The total hydrogen sulfide $\left(\mathrm{\Sigma}_{2} \mathrm{~S}\right)$ was estimated by measuring $\mathrm{H}_{2} \mathrm{~S}$ and $\mathrm{pH}$ at the same depth simultaneously as $\Sigma \mathrm{H}_{2} \mathrm{~S}$ depends on $\mathrm{pH}^{20}$ (calculations are presented in Supporting Information).

The profile measurements where made at the end phase 2 (anoxic) and 4 (oxic) for each core. To determine the surface of the sediments we have used magnifying lens $(10 \times)$. 
Phosphorus Extraction and Analysis. The phosphorus fractionation method used was based on the Psenner and Pucsko $^{21}$ extraction scheme. This extraction method has been used to evaluate the P-binding forms in lake sediments ${ }^{12,14}$ (Table 1). After each extraction step, samples were centrifuged

Table 1. Phosphorus Forms Extracted with the Different Solvents in the Sequential Extraction Procedure

\begin{tabular}{|c|c|c|c|}
\hline step & solvent & $\begin{array}{c}\mathrm{P}- \\
\text { fraction }\end{array}$ & $\mathrm{P}$ bounding forms \\
\hline 1 & $\mathrm{NH}_{4} \mathrm{Cl}(0.1 \mathrm{M})$ & SRP & $\begin{array}{l}\text { pore water-soluble phosphate and sediment } \\
\text { surface loosely adsorbed phosphate, algal } \\
\text { available phosphate. }\end{array}$ \\
\hline 2 & $\begin{array}{l}\mathrm{BD}(0.11 \mathrm{M}) \\
\quad \text { (Bicarbonate }- \\
\text { Dithionite) } 40{ }^{\circ} \mathrm{C}\end{array}$ & SRP & $\begin{array}{l}\text { redox-sensitive } \mathrm{P} \text {, mainly bound to } \mathrm{Fe} \text { - } \\
\text { hydroxide and Mn-hydroxide. }\end{array}$ \\
\hline 3 & $\begin{array}{l}\mathrm{NaOH}(1 \mathrm{M}) \text { at } \\
25^{\circ} \mathrm{C}\end{array}$ & SRP & $\begin{array}{l}\text { phosphate bound to metallic oxide (mainly } \\
\mathrm{Al} \text { ), and soluble inorganic P-compounds } \\
\text { in alkaline solution. }\end{array}$ \\
\hline 4 & $\mathrm{HCl}(0.5 \mathrm{M})$ & SRP & carbonate and Apatite- P \\
\hline 5 & $\begin{array}{l}\mathrm{NaOH}(1 \mathrm{M}) \text { at } \\
85^{\circ} \mathrm{C}\end{array}$ & $\mathrm{TP}$ & organic refractory $\mathrm{P}$ \\
\hline
\end{tabular}

at $7000 \mathrm{rpm}$, for $20 \mathrm{~min}$, and the supernatant was filtrated through a $0.45 \mu \mathrm{m}$ pore diameter membrane. The analysis of SRP was made by the molybdenum blue/stannous chloride method. ${ }^{22}$ The total-P (TP) analysis was achieved by an acid digestion of the samples with nitric acid $(5 \mathrm{~mL})$ and sulfuric acid $(1 \mathrm{~mL})$ at $250{ }^{\circ} \mathrm{C}$ for $90 \mathrm{~min}$, as detailed in Standard Methods of Water and Wastewater ${ }^{22}$ and further determination as SRP.

Bacteria Quantification. The bacterial quantification was made in natural intact sediment core before the experiment started. The amplification of real-time PCR products was carried out with a Chromo4 real-time PCR detector (MJ/BioRad) using SYBR Green as signal dye. PCR amplification was performed in a $25 \mu \mathrm{L}$ reaction mixture containing $20 \mu \mathrm{L}$ of master mix (iQ SYBR Green Supermix, Bio-Rad 170-8882), and $5 \mu \mathrm{L}$ of DNA template (concentrations ranged from 0.10 $\mathrm{ng} / \mu \mathrm{L}$ to $1.60 \mathrm{ng} / \mu \mathrm{L}$ ). Primers targeting the $16 \mathrm{~S}$ rRNA were used to quantify total bacteria, $1055 f / 1392 \mathrm{r}^{23}$ and Geobacteraceae as iron-reducing bacteria, Geo564f Geo840r. ${ }^{24}$ The purity of amplified products was checked by the appearance of a single melting peak obtained by increasing temperature from 62 to $95{ }^{\circ} \mathrm{C}$ at $0.2{ }^{\circ} \mathrm{C} / \mathrm{s}$. Data were analyzed using MJ OpticonMonitor 3.1 (MJ/Bio-Rad). Standard curves were generated from a 10 -fold dilution series of positive controls $\left(10^{1}\right.$ to $10^{8}$ target copies per reaction) included in duplicate in each PCR.

\section{RESULTS AND DISCUSSION}

As presented in Figure 2, the volcanic lake sediments that were under anoxic conditions released $\mathrm{P}$ from the $\mathrm{BD}$ and $\mathrm{NaOH}$ (at $85^{\circ} \mathrm{C}$ ) pools when compared with the initial conditions, as a result of reduction of $\mathrm{Fe}$ (III) to $\mathrm{Fe}$ (II) leading to solubilization of $\mathrm{Fe}$ mineral complexes $\left(\mathrm{Fe}_{x} \mathrm{O}_{y}(\mathrm{OH})_{z}\right)$ and organic matter mineralization, respectively. When the reactor was exposed to $\mathrm{O}_{2}, \mathrm{Fe}$ minerals readsorbed $\mathrm{P}$ as observed by the change in $\mathrm{P}$ concentration in the $\mathrm{BD}$ fraction (compare anoxic/oxic values in BD fraction, Figure 2). This is consistent with the classic paradigm that $\mathrm{Fe}$ (III) reduction in anoxic period from oxyhydroxide minerals will result in dissolution of the $\mathrm{Fe}-\mathrm{P}$ complex with concomitant P release. ${ }^{2-4}$ However, as Fe (III) is converted to $\mathrm{Fe}$ (II), two parallel reactions with opposite results will happen: 1 . Fe (II) will react with phosphate to produce vivianite $\left(\mathrm{Fe}_{3}\left(\mathrm{PO}_{4}\right)_{2}\right)$ acting as a $\mathrm{P}$ trap; and 2 . $\mathrm{Fe}$ (II) will react with $\Sigma \mathrm{H}_{2} \mathrm{~S}$ creating $\mathrm{FeS}$, which will exhaust the availability of Fe complexes for P binding. ${ }^{13}$ The presence and concentration of $\mathrm{\Sigma H}_{2} \mathrm{~S}$ in anoxic conditions was identified and quantified through microprofiling technique from the top sediment layers to deep layers (Figure 3).

As vivianite $\left(\mathrm{pKs}=36 \text {, at } 20^{\circ} \mathrm{C}\right)^{25}$ has a lower solubility than $\mathrm{FeS}\left(\mathrm{pKs}=2.9\right.$, at $\left.20^{\circ} \mathrm{C}\right),{ }^{26}$ it will precipitate first, trapping $\mathrm{P}$ in the sediments and preventing its dissolution to the water column. However, and as indicated by Gachter and Muller, ${ }^{13}$ increasing $\mathrm{\Sigma}_{2} \mathrm{~S}$ production will lead to $\mathrm{Fe}(\mathrm{II})$ sequestration and dissolution of $\mathrm{Fe}(\mathrm{II})$ minerals including vivianite, that will result in $\mathrm{P}$ release. Thus, during the anoxic phase, it is expected that $\mathrm{P}$ was first released by the $\mathrm{Fe}$ (III) minerals but recaptured by $\mathrm{Fe}(\mathrm{II})$ precipitating as vivianite, and then, released again after vivianite reaction with $\Sigma \mathrm{H}_{2} \mathrm{~S}$ due to its rising concentration (see conceptual model, Figure 4). This has resulted in a $\mathrm{P}$ concentration of $153 \mu \mathrm{g} / \mathrm{L} \pm 14 \mu \mathrm{g} / \mathrm{L}$ in the overlying water, at the end of the anoxic phase.

After the shift from anoxic to oxic phase (phase 4), P has been recaptured by Fe oxy-hydroxides as demonstrated by the rising BD fraction in Figure 2. Contrary to what should be expected, $\mathrm{P}$ concentration in water duplicated $(318 \mu \mathrm{g} / \mathrm{L} \pm 21$ $\mu \mathrm{g} / \mathrm{L}$, the $\mathrm{P}$ mass balance is demonstrated in Supporting Information). PSE results for the oxic phase indicate that $\mathrm{P}$ has been released from the aluminum oxy-hydroxide $\left(\mathrm{Al}_{x} \mathrm{O}_{y}(\mathrm{OH})_{z}\right)$ fraction (Figure $2-\mathrm{NaOH}$ ). This event was not a result of $\mathrm{O}_{2}$ concentration change, as $\mathrm{Al}$ oxy-hydroxides are not sensible to

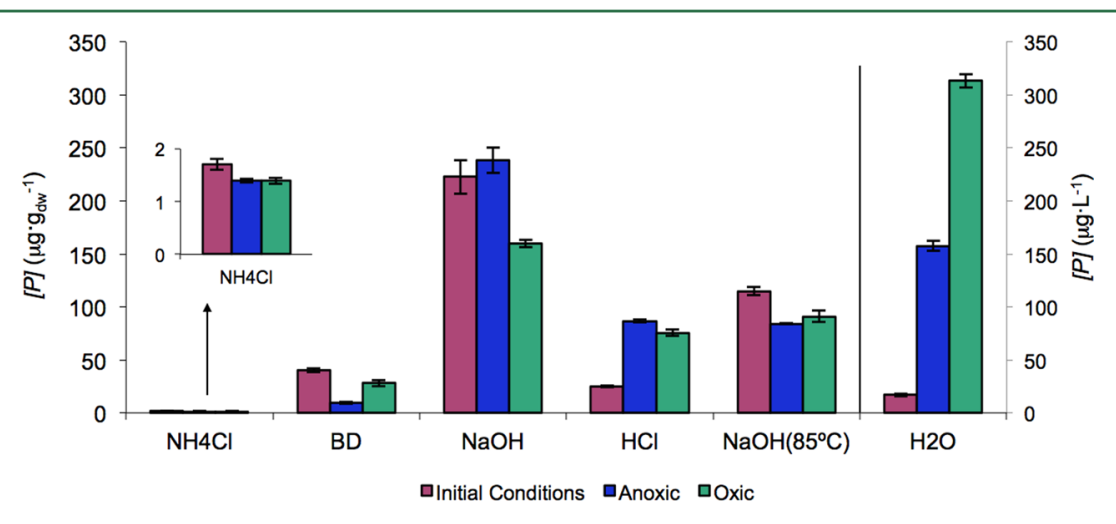

Figure 2. Results of $P$ sequential extraction (left side of the graph) and concentration in water (right side of the graph) for initial (phase 1), anoxic (phase 3) and oxic (phase 5) conditions. 

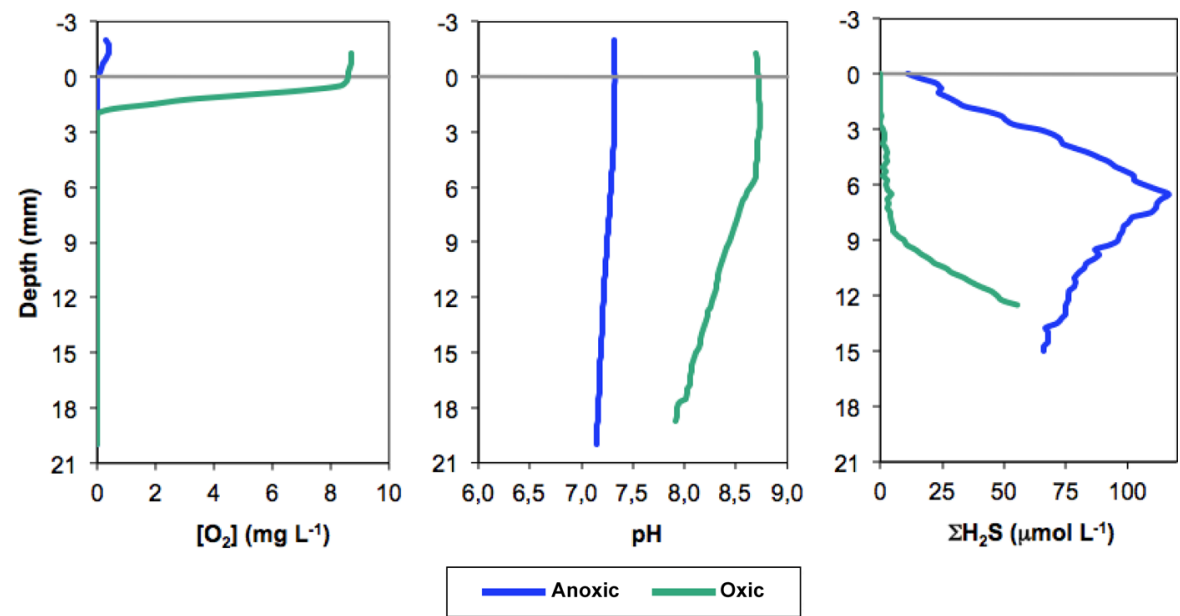

Figure 3. Microprofiling results, for $\mathrm{O}_{2}, \mathrm{pH}$, and $\Sigma \mathrm{H}_{2} \mathrm{~S}$ concentration, in oxic and anoxic conditions for the first $20 \mathrm{~mm}$ of sediment.

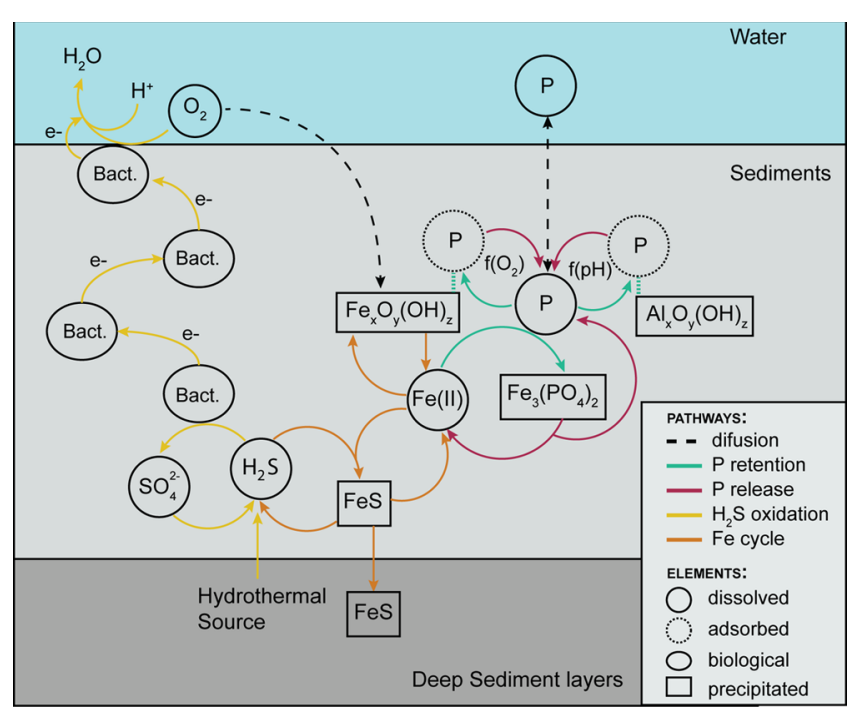

Figure 4. - Simplified conceptual model demonstrating the biologically mediated transport of electrons $(\mathrm{e}-$ ) from the anoxic sulfidic zone to the oxic zone at sediment water interface (top) with concomitant $\mathrm{H}^{+}$ consumption resulting in $\mathrm{pH}$ rising (adapted from Nielson et al.). ${ }^{16}$ Additionally, the model includes two $\mathrm{P}$ retention/release pathways base on mineral content: 1. Adsorption/desorption from Fe minerals $\left(\mathrm{Fe}_{x} \mathrm{O}_{y}(\mathrm{OH})_{z}\right)$ as a function of $\mathrm{O}_{2}$ concentration $\left[\mathrm{f}\left(\mathrm{O}_{2}\right)\right]$ and 2 . Adsorption/desorption from $\mathrm{Al}$ minerals $\left(\mathrm{Al}_{x} \mathrm{O}_{y}(\mathrm{OH})_{z}\right)$ as a function of $\mathrm{pH}$ concentration $[\mathrm{f}(\mathrm{pH})]$. Finally, the permanent sink of $\mathrm{Fe}$ in deep sediment layers was also considered.

redox potential shift, ${ }^{15}$ but to an increase in $\mathrm{pH}^{27}$ during oxic phase (Figure 3). It has been demonstrated that the $\mathrm{pH}$ range between 5 and 8 is optimal for $\mathrm{P}$ binding to $\mathrm{Al}$ hydroxides. ${ }^{15,28}$ The release of $\mathrm{P}$ bounded to $\mathrm{Al}(\mathrm{OH})_{3}$ was tested for six lake's sediments as a function of $\mathrm{pH}^{29}$ The results indicated high dissolution of $\mathrm{Al}(\mathrm{OH})_{3}$ with concomitant $\mathrm{P}$ release at $\mathrm{pH}$ above 8.5. During the oxic phase, $\mathrm{pH}$ increased above 8.7, which explain the partial $\mathrm{P}$ release that was bounded to $\mathrm{Al}$ oxyhydroxides by dissolution. We propose that this $\mathrm{pH}$ gradient can be associated with bioelectric currents as explained next.

In marine ecosystems it was indicated that bacteria could drive electrons trough a microbial network connected with nanowires from $\Sigma \mathrm{H}_{2} \mathrm{~S}$ in the anoxic layers to oxygen in the upper sediment layers (Figure 4). ${ }^{16,17}$ As electrons are driven through this bacterial network and/or as more recently suggested by filamentous bacteria, ${ }^{18,19}$ from anoxic layer to the oxic surface layers, $\mathrm{O}_{2}$ will be the last electron acceptor with concomitant $\mathrm{H}^{+}$consumption to produce water (Figure 4). This will result in a $\mathrm{pH}$ rise in the upper layers while acidification will occur in anoxic ones, as a result of $\Sigma \mathrm{H}_{2} \mathrm{~S}$ oxidation.

The microprofiling signature of $\Sigma \mathrm{H}_{2} \mathrm{~S}$ (Figure 3) suggests that this biologically driven electrical mechanism found in marine sediments may also be present in these volcanic sediments. The major evidence that this bioelectrochemical process was active in the present study is revealed by the change in $\Sigma \mathrm{H}_{2} \mathrm{~S}$ concentration profile after the $\mathrm{O}_{2}$ concentration shift (anoxic to oxic period), with concomitant $\mathrm{pH}$ gradient formation. The results presented in Figure 3 show that, during the oxic period, $\Sigma \mathrm{H}_{2} \mathrm{~S}$ is being consumed in the first $9 \mathrm{~mm}$ with concomitant decrease in concentration (compare $\Sigma \mathrm{H}_{2} \mathrm{~S}$ concentration between oxic and anoxic period in the first $9 \mathrm{~mm}$ of sediments). However, the oxygen profile indicates that it can diffuse only in the first $2 \mathrm{~mm}$ of sediment. Thus, $\Sigma \mathrm{H}_{2} \mathrm{~S}$ in deeper layer was not being oxidized by direct reaction with oxygen, but possibly through a microbial network capable of driving electrons from $\Sigma \mathrm{H}_{2} \mathrm{~S}$ in deep layers (until 9 $\mathrm{mm}$ depth) to $\mathrm{O}_{2}$ in the top layer. This process is additionally confirmed by the change in $\mathrm{pH}$ profile that shows a $\mathrm{pH}$ gradient formation with higher value in the top sediment layer when compared with the anoxic period. Although a more distinct $\mathrm{pH}$ peak in the oxic layer should be expected (when compared with experiences made in marine sediments ${ }^{16}$ ), there is still a small convex bend in $\mathrm{pH}$ profile, which can indicate that the process was active but ceased after 21 days of oxic period.

Moreover, Geobacteraceae-like iron reducing bacteria (IRB), which have the ability of driving electrons ${ }^{30}$ were identified in Furnas lake sediments and represented around $1.4 \pm 0.6 \%$ (Figure 5) of total bacteria $\left(8.48 \times 10^{8} \pm 8.93 \times 10^{7} \mathrm{cell} / \mathrm{g}\right.$ sediment). The bacterial profiles in the first $10 \mathrm{~cm}$ of sediment presented an almost homogeneous distribution (Figure 5). Other previous studies by the authors confirm the presence of these electroactive bacteria in Furnas lake sediments. ${ }^{31-33}$ If these Geobacteraceae-like bacteria were the main drivers of this mechanism or if other filamentous proteobacteria ${ }^{18,19}$ were majorly involved (or both) is still unknown, and will be object of further studies. 


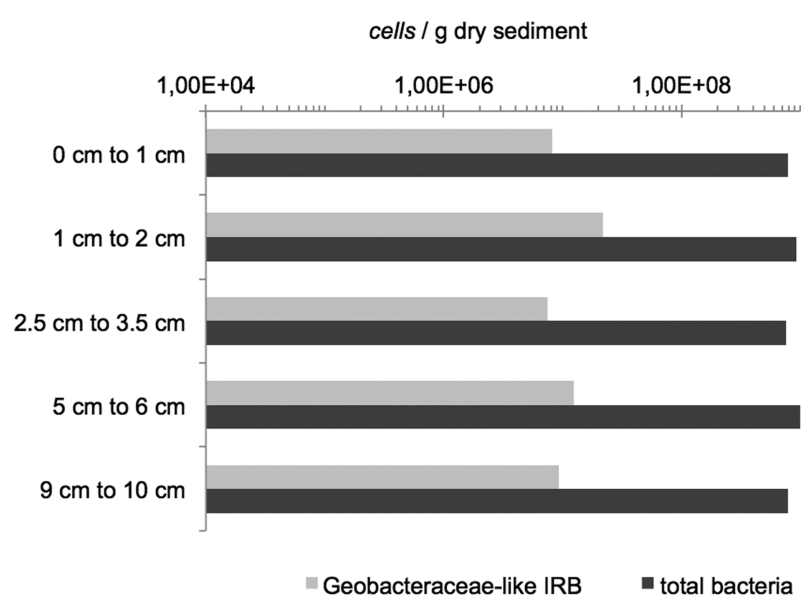

Figure 5. Geobacteraceae-like IRB and total bacteria profiles in sediments of the volcanic lake Furnas.

As biological drivers for bioelectrical process exist in Furnas volcanic lake sediments ${ }^{31-33}$ and microprofiling results are consistent with this fact, we propose that this is an important process leading to $\mathrm{pH}$ rising above 8 and consequently to instability of the $\mathrm{Al}-\mathrm{P}$ complex. ${ }^{15}$ Accordingly, $\mathrm{P}$ was released by diffusion through the sediment-water interface, increasing its concentration in the water column (see P release pathway from $\mathrm{Al}$ minerals in conceptual model - Figure 4).

This is the first time that $\Sigma \mathrm{H}_{2} \mathrm{~S}$ oxidation in suboxic layers spatially separated and pared to $\mathrm{O}_{2}$ reduction in top layers is being proposed in volcanic lake sediments-specifically relating the effects of this bioelectric process with $\mathrm{P}$ mobility. An interesting remark in the subject is that, if in one hand oxic periods will lead to $\mathrm{pH}$ gradients due to distant $\Sigma \mathrm{H}_{2} \mathrm{~S}$ oxidation and consequently to the dissolution of $\mathrm{P}$ bounded to $\mathrm{pH}$ sensitive matrixes, in the other hand the decrease in $\Sigma \mathrm{H}_{2} \mathrm{~S}$ concentration by oxidation will inhibit vivianite dissolution and consequently retain $\mathrm{P}$ in the sediments. ${ }^{8}$ Thus, before the selection of remediation techniques, aiming $\mathrm{P}$ retention by increasing $\mathrm{O}_{2}$ concentration in hypolimnium, both of these antagonist processes concerning $\mathrm{P}$ release/retention should be taken into account, and one should make an attempt to understand which of these processes is more pronounced, which can vary from lake to lake. Specifically in Furnas Lake, aeration has been implemented for more than a decade with no improvement in its trophic status (eutrophic lake). Although we cannot directly extrapolate our results (microcosm) to Furnas' diagenetic system, from the present results as well as from other results published elsewhere ${ }^{31-33}$ where the same sediments where used, we can conclude that there is bioelectric activity in Furnas' sediments. As hydrothermal sources exist in this lake and $\mathrm{H}_{2} \mathrm{~S}$ is continuously added to the system, ${ }^{34}$ which differentiate this system from other freshwater ones (with low sulfur-based elements, for example, $\mathrm{H}_{2} \mathrm{~S}, \mathrm{SO}_{4}{ }^{2-}$ ), biological activity related with the sulfur and iron cycle have an important influence on the diagenetic processes, ${ }^{30}$ though from this results we cannot estimate its contribution to $\mathrm{pH}$ variation. Other processes, denitrification and sulfate reduction can induce proton $\left(\mathrm{H}^{+}\right)$consumption with concomitant $\mathrm{pH}$ rising. Thus, for a direct extrapolation for the lake's diagenetic system, and quantification of the contribution of $\mathrm{H}_{2} \mathrm{~S}$ oxidation distantly pared with $\mathrm{O}_{2}$ reduction in $\mathrm{pH}$ increase (with concomitant $\mathrm{P}$ release), the same experiment should be made assessing the pore water concentration of dissolved $\mathrm{NO}_{3}{ }^{-}$,
$\mathrm{SO}_{4}^{2-}, \mathrm{Fe}^{2+}, \mathrm{Al}^{3+}$ and dissolved inorganic carbon (DIC) for each anoxic and oxic phase. ${ }^{17}$ The same tests should be made with in situ sediments in anoxic and oxic periods.

Finally, $\mathrm{Ca}$ minerals stability, similarly to $\mathrm{Al}$ minerals is mainly depend on $\mathrm{pH}^{15}$ rather then redox potential. ${ }^{21}$ As expected, bounded $\mathrm{P}$ to $\mathrm{Ca}$ minerals proved to be a nonredox sensitive fraction as the maximum adsorption occurred during the anoxic phase (Figure 2, $\mathrm{HCl}$ ). The refractory pool (Figure 2, $\mathrm{NaOH} 85{ }^{\circ} \mathrm{C}$ ) remained stable between anoxic and oxic conditions. The initial $\mathrm{P}$ content of this fraction was higher comparing with anoxic and oxic phases. Although this fraction represents $\mathrm{P}$ in refractory organic matter, the reduction of this fraction suggests that part of it was degradable and thus mineralized with concomitant $\mathrm{P}$ release to the water column.

Environmental Implication of Hypolimnium Aeration. This study confirms that $\mathrm{O}_{2}$ has an impact on Fe minerals stability where $\mathrm{P}$ is adsorbed. However, sediments may also release $\mathrm{P}$ from other matrixes that are not redox sensitive but are sensible to $\mathrm{pH}$ (e.g., $\mathrm{Al}$ minerals). In the present case, $\mathrm{P}$ extractable by $\mathrm{NaOH}$, corresponding mainly to $\mathrm{Al}$ minerals bounded $\mathrm{P}$ was almost 3 times higher than the redox sensitive fraction ( $\mathrm{Fe}$ minerals bounded $\mathrm{P}-\mathrm{BD}$ fraction). This $\mathrm{P}$ release occurred during the oxic period, demonstrating that $\mathrm{O}_{2}$ variation can have a minor positive effect on $\mathrm{P}$ retention by iron minerals when compared with the pronounced negative effect in $\mathrm{P}$ release from organic mater (due to increased oxidation) and other metallic mineral matrixes by $\mathrm{pH}$ shift (dissolution of $\mathrm{Al}$ minerals) or $\mathrm{\Sigma H}_{2} \mathrm{~S}$ presence in deeper layers (resulting in vivianite dissolution) of volcanic lakes.

Bioelectrical processes coupling $\mathrm{O}_{2}$ reduction in top sediment layers with $\mathrm{\Sigma}_{2} \mathrm{~S}$ reduction in deeper layers for almost a centimeter-long, is proposed to be one of the main contributing process for $\mathrm{pH}$ rising during oxic phase, thus, enabling $\mathrm{P}$ release caused by dissolution of $\mathrm{pH}$-sensitive matrixes. Therefore, aerated hypolimnium in volcanic lakes, aiming $\mathrm{P}$ retention, may be counter-productive.

In conclusion, internal $\mathrm{P}$ is controlled by a complex biogeochemical system that is lake specific. Therefore, each lake should be assessed for their biological and abiotic sediment components before aeration and destratification processes are implemented. Additionally, we suggest that sediment modeling should be used to assess the dynamics of P mobility of such complex system and to support decision-making in lakes management, namely in eutrophication control.

\section{ASSOCIATED CONTENT}

\section{S Supporting Information}

Additional information as noted in the text. This material is available free of charge via the Internet at http://pubs.acs.org.

\section{AUTHOR INFORMATION}

\section{Corresponding Author}

*E-mail: dribeiro@ciimar.up.pt.

\section{Notes}

The authors declare no competing financial interest.

\section{ACKNOWLEDGMENTS}

We are indebted to Dr. Dina Medeiros and Prof. Virgílio Cruz for their suggestions and technical advice, and Mr. José Gouveia for his kind support on data collection. We also thank Prof. Lars Peter Nielsen for his valuable comments, as well as Dr. Lars Larsen and the Unisense team for the training on microsensor 
profiling. This work was partly supported by the Azores Government (contract no. 4/2008/DROTRH) and NOVIWAM project funding provided by the European Union under the 7th Framework Programme for Research and Technological Development (Grant Agreement no. 245460). The Foundation for Science and Technology grants, SFRH/BD/25653/2005 awarded to Daniel Ribeiro and SFRH/BPD/80528/2011 awarded to Gilberto Martins, are also acknowledged.

\section{REFERENCES}

(1) Schindler, D. W. The dilemma of controlling cultural eutrophication of lakes. Proc. Biol. Sci. 2012, 279, 4322-33.

(2) Einsele, W. Über die Beziehungen des Eisenkreislaufs zum Phosphatkreislauf im eutrophen See. Arch. Hydrobiol. 1936, 29, 664686.

(3) Mortimer, C. H. The exchange of dissolved substances between mud and water in lakes. J. Ecol. 1941, 29, 280-329.

(4) Mortimer, C. H. The exchange of dissolved substances between mud and water in lakes II. J. Ecol. 1942, 30, 147-201.

(5) Mortimer, C. H. Chemical exchanges between sediments and water in the Great Lakes-speculations on probable regulatory mechanisms. Limnol. Ocean 1971, 16 (2), 387-404.

(6) Bostrom, B.; Andersen, J. M.; Fleischer, S.; Jansson, M. Exchange of phosphorus across the sediment-water interface. Ecosystems 1988, 244, 229-244.

(7) Hupfer, M.; Lewandowski, J. Oxygen Controls the Phosphorus Release from Lake Sediments - a Long-Lasting Paradigm in Limnology. Int. Rev. Hydrobiol. 2008, 93 (4-5), 415-432.

(8) Gächter, R.; Wehrli, B. Ten years of artificial mixing and oxygenation: No effect on the internal phosphorus loading of two eutrophic lakes. Environ. Sci. Technol. 1998, 32 (23), 3659-3665.

(9) Schauser, I.; Chorus, I. Assessment of internal and external lake restoration measures for two Berlin lakes. Lake Reservoir Manage. 2007, 23 (4), 366-376.

(10) Driscoll, C. T.; Effler, S. W.; Auer, M. T.; Doerr, S. M.; Penn, M. R. Supply of phosphorus to the water column of a productive hardwater lake: Controlling mechanisms and management considerations. Hydrobiologia 1993, 02, 61-72.

(11) Kopácek, J.; Borovec, J.; Hejzlar, J.; Ulrich, K.; Norton, S. a.; Amirbahman, A. Aluminum control of phosphorus sorption by lake sediments. Environ. Sci. Technol. 2005, 39 (22), 8784-9.

(12) Dittrich, M.; Chesnyuk, a; Gudimov, a; McCulloch, J.; Quazi, S.; Young, J.; Winter, J.; Stainsby, E.; Arhonditsis, G. Phosphorus retention in a mesotrophic lake under transient loading conditions: Insights from a sediment phosphorus binding form study. Water Res. 2013, 47 (3), 1433-47.

(13) Gächter, R.; Müller, B. Why the phosphorus retention of lakes does not necessarily depend on the oxygen supply to their sediment surface. Limnol. Oceanogr. 2003, 48, 929-933.

(14) Ribeiro, D. C.; Martins, G.; Nogueira, R.; Cruz, J. V.; Brito, A. G. Phosphorus fractionation in volcanic lake sediments (AzoresPortugal). Chemosphere 2008, 70, 1256-1263.

(15) Simmons, J. A. Phosphorus removal by sediments in stream contaminated with acid mine drainage. Water, Air, Soil Pollut. 2010, 209, 123-132.

(16) Nielsen, L. P.; Risgaard-Petersen, N.; Fossing, H.; Christensen, P. B.; Sayama, M. Electric currents couple spatially separated biogeochemical processes in marine sediment. Nature 2010, 463 (7284), 1071-4.

(17) Risgaard-Petersen, N.; Revil, A.; Meister, P.; Nielsen, L. P. Sulfur, iron-, and calcium cycling associated with natural electric currents running through marine sediment. Geochim. Cosmochim. Acta 2012, 92, 1-13.

(18) Pfeffer, C.; Larsen, S.; Song, J.; Dong, M.; Besenbacher, F.; Meyer, R. L.; Kjeldsen, K. U.; Schreiber, L.; Gorby, Y.; El-Naggar, M. Y.; Leung, K. M.; Schramm, A.; Risgaard-Petersen, N.; Nielsen, L. P. Filamentous bacteria transport electrons over centimetre distances. Nature 2012, 491, 218-21.
(19) Schauer, R.; Risgaard-Petersen, N.; Kjeldsen, K. U.; Tataru Bjerg, J. J.; B Jørgensen, B.; Schramm, A.; Nielsen, L. P. Succession of cable bacteria and electric currents in marine sediment. ISME J. 2014, $1-9$.

(20) Jeroschewski, P.; Steuckart, C.; Kühl, M. An amperometric microsensor for the determination of $\mathrm{H}_{2} \mathrm{~S}$ in aquatic environments. Anal. Chem. 1996, 68, 4351-4357.

(21) Psenner, R.; Pucsko, R. Phosphorus fractionation: Advantages and limits of the method for the study of sediment $\mathrm{P}$ origins and interactions. Arch. Hydrobiol. Beih 1988, 30, 43-59.

(22) APHA, AWWA, and WEF. Standard Methods of Water and Wastewater, 20th ed.; American Public Health Association: Washington D.C., 1998; ISBN-10:0875532357.

(23) Harms, G.; Layton, A. C.; Dionisi, H. M.; Gregory, I. M.; Garrett, V. M.; Hawkins, S. A.; Robinson, K. G.; Sayler, G. S. Real-time PCR quantification of nitrifying bacteria in a municipal wastewater treatment plant. Environ. Sci. Technol. 2003, 37, 343-351.

(24) Bedard, D. L.; Ritalahti, K. M.; Löffler, F. E. The Dehalococcoides population in sediment-free mixed cultures metabolically dechlorinates the commercial polychlorinated biphenyl mixture Aroclor 1260. Appl. Environ. Microbiol. 2007, 73, 2513-2521.

(25) Al-Borno, A.; Tomson, M. B. The temperature dependence of the solubility product constant of vivianite. Geochim. Cosmochim. Acta 1994, 58, 5373-5378.

(26) Davison, W. The solubility of iron sulphides in synthetic and natural waters at ambient temperature. Aquat. Sci. 1991, 54 (4), 309329.

(27) Lake, T.; Jin, X.; Wang, S.; Pang, Y.; Chang, F. Phosphorus fractions and the effect of $\mathrm{pH}$ on the phosphorus release of the sediments from different trophic areas. Environ. Pollut. 2006, 139, $288-295$.

(28) Lijklema, L.; Koelmans, A.; Portielje, R. Water quality impacts of sediment pollution and the role of early diagenesis. Water Sci. Technol. 1993, 28 (8-9), 1-12.

(29) Reitzel, K.; Jensen, H. S.; Egemose, S. pH dependent dissolution of sediment aluminum in six Danish lakes treated with aluminum. Water Res. 2013, 47, 1409-20.

(30) Lovley, D. R.; Holmes, D. E.; Nevin, K. P. Dissimilatory Fe(III) and Mn(IV) Reduction. Adv. Microb. Physiol. 2004, 49, 219-86.

(31) Martins, G.; Peixoto, L.; Ribeiro, D. C.; Parpot, P.; Brito, A. G.; Nogueira, R. Towards implementation of a benthic microbial fuel cell in lake Furnas (Azores): Phylogenetic affiliation and electrochemical activity of sediment bacteria. Bioelectrochemistry 2010, 78 (1), 67-71.

(32) Martins, G.; Terada, A.; Ribeiro, D. C.; Corral, A. M.; Brito, A. G.; Smets, B. F.; Nogueira, R. Structure and activity of lacustrine sediment bacteria involved in nutrient and iron cycles. FEMS Microbiol. Ecol. 2011, 77, 666-679.

(33) Martins, G., Ribeiro, D. C., Terada, A., Smets, B. F., Brito, A. G., Nogueira, R. Phylogeny and Activity of Proteobacteria in lake sediments. In Proteobacteria: Phylogeny, Metabolic Diversity and Ecological Effects; Sezenna, M. L., Ed.; Nova Science Publishers, Inc., 2011; ISBN: 978-1-61761-198-8.

(34) Cruz, J.; Antunes, P.; Amaral, C.; Franca, Z.; Nunes, J. Volcanic lakes of the Azores archipelago (Portugal): Geological setting and geochemical characterization. J. Volcanol. Geotherm. Res. 2006, 156, $135-157$ 